JIKAP PGSD: Jurnal Ilmiah Ilmu Kependidikan

Vol, 4. No,1. Tahun 2020

e-ISSN: 2597-4440 dan p-ISSN: 2597-4424

This work is licensed under a Creative Commons Attribution

4.0 International License

\title{
Kinerja Pegawai Pada Fakultas Ilmu Pendidikan Universitas Negeri Makassar
}

\author{
Syamsurijal Basri ${ }^{1}$, Abdul Saman ${ }^{2}$ \\ ${ }^{1,2}$ Fakultas Ilmu Pendidikan, Universitas Negeri Makassar \\ Email: ${ }^{1}$ rijal@unm.ac.id \\ 2abdulsaman72@gmail.com
}

\begin{abstract}
Abstrak. Penelitian ini bertujuan untuk memperoleh gambaran Kinerja Pegawai pada Fakultas Ilmu Pendidikan Universitas Negeri Makassar. Metode peneliatian yang di gunakan adalah kualitatif dengan pendekatan eksplorasi. Sumber data dalam penelitian ini melibatkan tujuh partisipan. Teknik analisis data yang digunakan yaitu dengan reduksi data, paparan data dan penarikan kesimpulan atau verifikasi data. Hasil Penelitian menunjukkan bahwa Kinerja Pegawai pada Fakultas Ilmu Pendidikan Universitas Negeri Makassar menunujukkan bahwa: (1) Kecepatan pegawai dalam menyelesaikan pekerjaan sudah optimal, kedisiplinan pegawai yang cukup tinggi, pekerjaan yang dilakukan dapat diselesaikan tepat waktu, memberikan kemudahan dalam pelayanan, dalam melakukan pelayanan sesuai dengan jadwal kerja yang telah di tetapkan. (2) Kemampuan pegawai secara keseluruhan cukup optimal, pekerjaan dilakukan dilakukan secara manual dan menggunakan teknologi komputer, kemampuan pegawai mengoperasikan komputer dalam mengerjakan tugas-tugasnya masih kurang. (3) Inisiatif pegawai belum optimal, Sebagian besar pegawai bekerja jika diperintahkan oleh pimpinan, kurang kreatif dalam melaksanakan pekerjaan, terdapat beberapa pegawai waktu kerja dilakukan untuk bersantai, hanya beberapa pegawai yang dapat menemukan solusi sendiri terhadap permasalahan pekerjaannya.
\end{abstract}

Kata kunci: Kinerja Pegawai, Kecepatan, Kemampuan, Inisiatif.

\begin{abstract}
This study examines the employees performance at the Faculty of Education, Makassar State University. The research method used was qualitative with an exploratory approach. The data source in this study involved seven participants. Data analysis techniques used are data reduction, data exposure and conclusion drawing or data verification. The results showed that the Performance of Employees at the Faculty of Education, Makassar State University showed that: (1) The speed of employees in completing work was optimal, employee discipline was quite high, work performed could be completed on time, providing convenience in service, in carrying out services in accordance with a work schedule that has been set. (2) The ability of employees as a whole is quite optimal, work is done manually and uses computer technology, the ability of employees to operate computers in carrying out their tasks is still lacking. (3) Employee initiatives are not optimal, Most employees work if instructed by the leadership, are less creative in carrying out work, there are some employees working time to relax, only a few employees can find their own solutions to work problems.
\end{abstract}

Keywords: Employee Performance, Quickness, Ability, Initiative. 


\section{PENDAHULUAN}

Setiap organisasi dalam menjalankan kegiatan selalu mengarah pada pencapaian tujuan yang didasari oleh Visi, Misi organisasi. Salah satu faktor yang menjadi syarat untuk mencapai tujuan suatu organisasi adalah kinerja pegawai yang bekerja didalamnya. Organisasi merupakan suatu kesatuan yang utuh dan kompleks yang didalamnya terdapat sumber daya manusia yang saling bekerjasama untuk mencapai suatu tujuan. Suatu organisasi yang baik jika dapat mencapai tujuan dapat dilakukan secara efektif dan efisien serta profesional. Amidjaja (Nasarudin \& Muslimin, 2018) menuturkan bahwa kefektifan kinerja juga ditentukan oleh profesionalisme manajemen kerja.

Demikian halnya pada instansi pemerintah keberhasilan instansi terlihat dari pencapaian program dan pelayanan yang di berikan kepada masyarakat, pelayanan ini tercermin dari kinerja yang tercermin pada para pegawai atau staf yang ada di dalamnya, kinerja pegawai pada instansi di tunjukkan dalam bentuk kerja terhadap apa yang di lakukan oleh pegawai yang sesuai dengan tupoksinya masingmasing.

Kinerja pegawai sangat berpengaruh terhadap seberapa banyak seseorang dapat memberikan kontribusi terhadap instansi dimana dia bekerja. Setiap pekerjaan memiliki kriteria pekerjaan yang spesifik kerja yang harus diselesaikan oleh pegawai. Setiap organisasi perlu mengetahui kelamahan dan kelebihan pegawainya sebagai landasan untuk memperbaiki kinerja pegawai dalam rangka meningkatkan produktifitas dan pengembangan pegawai sehingga kinerja pegawai pada setiap instansi harus dioptimalkan demi tercapainya tujuan instansi tersebut. Untuk itu perlu dilakukan penilaian kinerja secara periodik yang berorientasi pada masa lalu atau masa yang akan datang. Penilaian disini dimaksudkan untuk mengetahui apakah unjuk kerja dari pegawai sudah memenuhi standar kerja yang diharapkan atau belum.

Kenerja pegawai merupakan hasil yang dicapai seseorang menurut ukuran yang berlaku dalam kurum waktu tertentu berkenaan dengan pekerjaan dan serta perilaku dan tindakannya. Keberhasilan seseorang dalam menjalankan tugasnya tergantung pada penilaian kinerja yang dikakukan oleh organisasi. Penilaian kinerja ini sangat di perlukan untuk memberikan gambaran sebagai masukan dalam mengambil keputusankeputusan untuk kemajuan organisasi.

Berdasarkan undang-undang nomor 5 tahun tahun 2014 tentang Apatur Sipil Negara (ASN) dimana dalamnya lebih berfokus pada pada sasaran kenerja pegawai (SKP) sehingga dengan demikian kinerja pegawai lebih di fokuskan karena merupakan gabungan antara Sasaran kinerja pegawai dan perilaku kerja.("UU5-2014 Aparatur Sipi 1Negara.pdf," t.t.)

Penelitian ini bertujuan untuk memperoleh gambaran kinerja pegawai dengan indikator kecepatan kerja, kemampuan, dan inisiatif. Kecepatan kerja dalam menyelesaiakan tugasnya, kemampuan dlaam mengerjakan pekerjaan yang di berikan, inisitaif dalam enyelesaikan masalah pekerjaannya sendiri agar tidak terjadi kemandulan dalam pekerjaan

Telah banyak penelitian terdahulu yang telah dilakukan terkait dengan kinerja pegawai namun dalam penelitian ini lebih untuk menambah referensi pengetahuan yang berkaitan dengan kinerja pegawai dengan indikator Kecepatan Kerja, Kemampuan, Inisiatif

Beberapa hasil penelitian yang terkait dengan kinerja pegawai. Penelitian tentang Kinerja pegawai Sekolah Tinggi Seni Indonesia (STSI) Bandung dinilai sangat baik. Hal ini dilihat dari indikator-indikator kinerja yang baik diantaranya menerapkan prinsip kejujuran, ketaatan, inisiatif, dan memiliki rasa tanggung jawab yang besar,(Anggraeni, 2011)

Penelitian lain yang dilakukan oleh (Rustiani, Junaid, \& Farzan, 2017) menunjukkan kinerja pegawai puskesmas wangi-wangi sesuai dengan profesi masing-masing. Sikap pegawai puskesmas wangi-wangi mulai sopan dalam hal menyapa pasien dan belum sopan dalam hal merawat pasien. Penampilan pegawai puskesmas wangi-wangi belum seragam dalam berpakaian di sebabkan karena kurangnya penegakan aturan mengenai penampilan yang rapih. Perhatian pegawai puskesmas cukup mendengarkan keluhan pengunjung. Tindakan pegawai, tidak semua pegawai menanggapi keluhan pengunjung. Tanggung Jawab pegawai terhadap tugas yang diberikan dan menjaga lembaga.

Kinerja adalah hasil kerja karyawan baik dari segi kualitas maupun kuantitas berdasarkan standar kerja yang telah ditentukan (Sriwidodo \& Haryanto, 2010)

Kinerja dapat diartikan performance didalam melaksanakan pekerjaan dan 
bagaimana hasil dari pekerjaan. Hal ini dikemukakan oleh (Wibowo,2007) bahwa kinerja adalah hasil yang dicapai dari pekerjaan. Kinerja berkaitan erat dengan pekerjaan yang dilakukan karena berhubungan dengan tujuan yang ingin dicapai.

Kinerja sebagai hasil-hasil fungsi pekerjaan atau kegiatan seseorang atau kelompok dalam suatu organisasi yang dipengaruhi oleh berbagai faktor untuk mencapai tujuan organisasi dalam periode waktu tertentu, (Kamrida \& Nasrullah, 2016)

Kinerja juga dapat diartikan perbuatan dalam melaksanakan pekerjaan mengatakan bahwa kinerja terjemahan dari performance sehingga memiliki arti perbuatan, pelaksanaan pekerjaan, prestasi kerja, pelaksanaan pekerjaan yang berdaya guna. Lebih lanjut lagi di kemukakan bahwa kinerja adalah pencapaian seseorang berkenan dengan tugas yang diberikan kepadanya, (Sedarmayanti (2009)

Menurut (Mangkunegara , 2007) Istilah kinerja berasal dari kata " job performance" atau " actual performence". yaitu hasil kerja yang dicapai oleh seseorang dalam melaksanakan tugasnya sesuai dengan tanggung jawab yang diberikan kepadanya.

\section{Faktor-Faktor yang Mempengaruhi Kinerja Pegawai}

Kinerja pegawai dapat tercapai jika di pengaruhi beberapa faktor. Menurut Moorhead dan Chung/Megginson, kinerja pegawai dipengaruhi oleh beberapa faktor, yaitu ;

a. Kualitas Pekerjaan (Quality of Work)

Merupakan tingkat baik atau buruknya sesuatu pekerjaan yang diterima bagi seorang pegawai yang dapat dilihat dari segi ketelitian dan kerapihan kerja, keterampilan dan kecakapan.

b. Kuantitas Pekerjaan (Quantity of Work)

Merupakan seberapa besarnya beban kerja atau sejumlah pekerjaan yang harus diselesaikan oleh seorang pegawai. Diukur dari kemampuan secara kuantitatif didalam mencapai target atau hasil kerja atas pekerjaan-pekerjaan baru.

c. Pengetahuan Pekerjaan (Job Knowledge)

Merupakan proses penempatan seorang pegawai yang sesuai dengan background pendidikan atau keahlian dalam suatu pekerjaan. Hal ini ditinjau dari kemampuan pegawai dalam memahami hal-hal yang berkaitan dengan tugas yang mereka lakukan.

\section{d. Kerjasama Tim (Teamwork)}

Melihat bagaimana seorang pegawai bekerja dengan orang lain dalam menyelesaikan suatu pekerjaan. Kerjasama tidak hanya sebatas secara vertikal ataupun kerjasama antar pegawai, tetapi kerjasama secara horizontal merupakan faktor penting dalam suatu kehidupan organisasi yaitu dimana antar pimpinan organisasi dengan para pegawainya terjalin suatu hubungan yang kondusif dan timbal balik yang saling menguntungkan.

\section{e. Kreatifitas (Creativity)}

Merupakan kemampuan seorang pegawai dalam menyelesaikan pekerjaannya dengan cara atau inisiatif sendiri yang dianggap mampu secara efektif dan efisien serta mampu menciptakan perubahan-perubahan baru guna perbaikan dan kemajuan organisasi.

\section{f. Inovasi (Inovation)}

Kemampuan menciptakan perubahanperubahan baru guna perbaikan dan kemajuan organisasi.Hal ini ditinjau dari ide-ide cemerlang dalam mengatasi permasalahan organisasi.

g. Inisiatif (initiative)

Melingkupi beberapa aspek seperti kemampuan untuk mengambil langkah yang tepat dalam menghadapi kesulitan, kemampuan untuk melakukan sesuatu pekerjaan tanpa bantuan, kemampuan untuk mengambil tahapan pertama dalam kegiatan.

\section{Indikator Kinerja Pegawai}

Indikator kinerja pegawai di ukur berdasarkan kriteria tertentu. Menurut T.R. Michel dalam Rizky (2001) indikator kinerja meliputi:

a) Kualitas pelayanan (Quality of work), yaitu kualitas pekerjaan yang dihasilkan dapat memuaskan bagi penggunanya atau tidak, sehingga hal ini dijadikan sebagai standar kerja.

b) Komunikasi (Communication), yaitu kemampuan pegawai dalam berkomunikasi dengan baik kepada konsumen

c) Kecepatan (Promptness), yaitu kecepatan bekerja yang diukur oleh tingkat waktu, sehingga pegawai dituntut untuk bekerja cepat dalam mencapai kepuasan dan peningkatan kerja.

d) Kemampuan (Capability), yaitu kemampuan dalam melakukan pekerjaan semaksimal mungkin.

e) Inisiatif (Intiative), yaitu setiap pegawai mampu menyelesaikan masalah pekerjaannya 
sendiri agar tidak terjadi kemandulan dalam pekerjaan.

Menurut Schuler \& Dowling (Keban 2000) kinerja dapat diukur dari:

a) Kuantitas kerja

b) Kualitas Kerja

c) Kerjasama

d) Mengetahui tentang kerja

e) Kemandirian kerja

f) Kehadiran dan ketepatan waktu

g) Pengetahuan tentang kebijakan dan tujuan organisasi

h) Inisiatif dan menyampaikan ide-ide sehat

i) Kemampuan supervisi dan teknik

Selanjutanya indikator pengukuran tersebut diatas adalah indicator umum yang sering dilakukan kecuali kemampuan supervisi dan teknik, sedangkan indi kator kinerja juga dapat di ukur melalui (1) pemahaman pengetahuan, (2) keahlian, (3) kepegawaian, (4) perilaku yang di perlukan untuk melaksanakan suatu pekerjaan denga baik (Sedarmayanti, 2007).

Dalam mengukur kinerja terdapat kritaria yang di jadikan acuan menurut (Wirawan, 2009) kriteria tersebut adalah:

a) Kuantitatif (sebarapa banyak)

b) Kualitatif (seberapa baik)

c) Ketepatan waktu pelaksanaan tugas atau penyelesaian produk

d) Efektifitas Penggunaan sumber organisasi

e) Cara melakukan pekerjaan

f) Efek atau suatu Upaya

g) Metode Melaksanakan tugas

\section{METODE PENELITIAN}

Metode peneliatian yang di gunakan adalaha kualitatif dengan pendekatan eksplorasi. Teknik pengumpulan data berupa wawancara yang dilakukan untuk menggali informasi terkait dengan kinerja pegawai dengan indikator kecepatan kerja, kemampuan, dan inisiatif, dan dokumentasi berupa data yang mendukung jawaban informan. Informan dalam penelitian ini terdiri tujuh partisipan yang berasal dari staf, kepala sub bagian, dan pimpinan pada Fakultas Ilmu Pendidikan, sebagai berikut:

Tabel 1: Partisipan Informan Penelitian

\begin{tabular}{lccc}
\hline No & Partisipan & $\begin{array}{c}\text { Jenis } \\
\text { Kelamin }\end{array}$ & Pendidikan \\
\hline 1 & $\begin{array}{c}\text { Partisipan } \\
1\end{array}$ & Perempuan & SMA \\
& $\begin{array}{c}\text { Partisipan } \\
2\end{array}$ & Perempuan & S1 \\
& & & \\
\hline
\end{tabular}

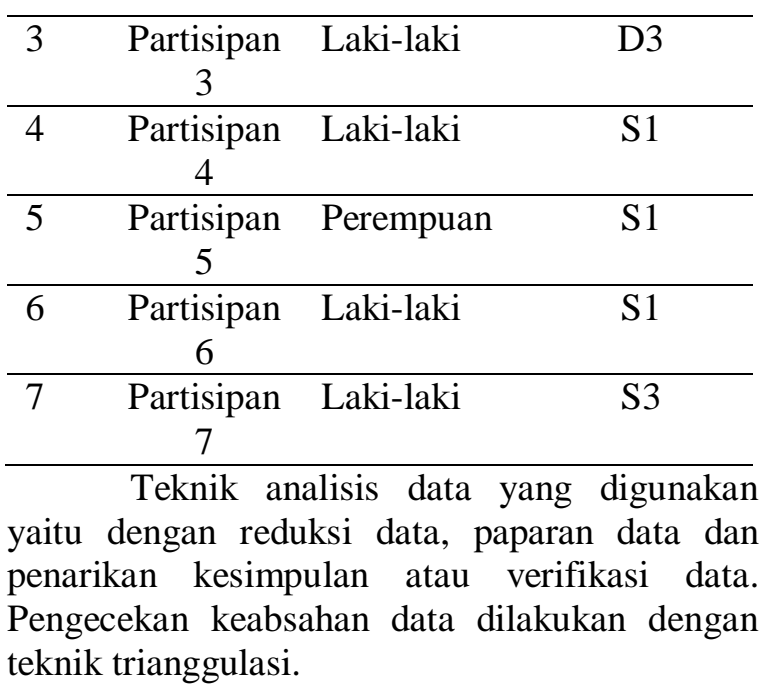

\section{HASIL PENELITIAN}

Hasil Penelitian menunjukkan bahwa Kinerja pegawai pada Fakultas ilmu pendidikan UNM dengan indikator kecepatan dalam menyelesaikan pekerjaan di tunjukkan dalam bentuk kedisiplinan pegawai yang cukup tinggi, pekerjaan yang dilakukan dapat diselesaikan tepat waktu, dan memberikan kemudahan dalam pelayanan, dalam melakukan pelayanan sesuai dengan jadwal kerja yang telah di tetapkan. Kecepatan kerja yang dilakukan pegawai tidak terlepas dari adanya integritas yang dimiliki oleh pegawai sehingga berdampak pada kepuasan pelanggangan, hal ini senada yang di kemukakan T.R. Michel dalam Rizky (2001) salah satu indikator kinerja Kecepatan (Promptness), yaitu kecepatan bekerja yang diukur oleh tingkat waktu, sehingga pegawai dituntut untuk bekerja cepat dalam mencapai kepuasan dan peningkatan kerja. Kecepatan kerja juga merupakan salah satu aspek pelayanan yang terbaik dalam memenuhi harapan dan kebutuhan pelanggan yang tetap mengedepankan pemenuhan standar kualitas agar sesuai dengan harapan dan kebutuhan pelanggan atau organisasi (Maddy, 2009).

Indikator kemampuan menunjukkan bahwa pegawai Fakultas llmu Pendidikan UNM secara keseluruhan kemampuan dalam menyelesaikan pekerjaan cukup optimal, pekerjaan dilakukan dalam dua bentuk yaitu pekerjaan dilakukan secara manual dan pekerjaan diselesaikan dengan menggunakan teknologi komputer, Beberapa pegawai masih senang mengerjakan tugasnya secara manual sehingga efektifitas dalam bekerja belum optimal. Hal ini disebabkan oleh kurangnya kemampuan pegawai khususnya dalam hal mengoperasikan komputer untuk mengerjakan 
tugas-tugasnya. Menurut Lowser dan poter (Anggraeni, 2011) mendefinisikan Kemampuan sebagai karakteristik individual seperti intelegensia, manual skill, traits yang merupakan kekuatan potensial seseorang untuk berbuat dan sifatnya stabil. Di jelaskan juga oleh T.R. Michel dalam Rizky (2001) indikator kinerja Kemampuan (Capability), yaitu kemampuan dalam melakukan pekerjaan semaksimal mungkin

Indikator inisiatif menunjukkan bahwa pegawai Fakultas Ilmu Pendidikan UNM belum optimal. Hal ini disebabkan oleh sebagian besar pegawai akan bekerja jika diperintahkan oleh pimpinan, pegawai masih kurang kreatif dalam melaksanakan pekerjaan, terdapat beberapa pegawai waktu kerja dilakukan untuk bersantai, hanya beberapa pegawai yang mampu bekerja secara kreatif dan dapat menemukan solusi sendiri terhadap permasalahan dalam pekerjaannya. Menurut T.R. Michel dalam Rizky (2001) Inisiatif (Intiative), yaitu setiap pegawai mampu menyelesaikan masalah pekerjaannya sendiri agar tidak terjadi kemandulan dalam pekerjaan

\section{SIMPULAN DAN SARAN}

Kinerja Pegawai pada Fakultas Ilmu Pendidikan Universitas Negeri Makassar menunujukkan bahwa: (1) Kecepatan pegawai dalam menyelesaikan pekerjaan sudah optimal, kedisiplinan pegawai yang cukup tinggi, pekerjaan yang dilakukan dapat diselesaikan tepat waktu, memberikan kemudahan dalam pelayanan, dalam melakukan pelayanan sesuai dengan jadwal kerja yang telah di tetapkan. (2) Kemampuan pegawai secara keseluruhan cukup optimal, pekerjaan dilakukan dilakukan secara manual dan menggunakan teknologi komputer, kemampuan pegawai mengoperasikan komputer dalam mengerjakan tugas-tugasnya masih kurang. (3) Inisiatif pegawai belum optimal, Sebagian besar pegawai bekerja jika diperintahkan oleh pimpinan, kurang kreatif dalam melaksanakan pekerjaan, terdapat beberapa pegawai waktu kerja dilakukan untuk bersantai, hanya beberapa pegawai yang dapat menemukan solusi sendiri terhadap permasalahan pekerjaannya.

Adapaun saran yang dapat diajukan adalam penelitian ini adalah: (1) pegawai perlu meningkatkan kemampuan dalam mengoperasikan sistem operasi komputer dalam membantu segala pekerjaannya. (2) pimpinan fakultas perlu memfasilitasi segala kebutuhan pegawai dalam menjalankan tugas-tugasnya dengan menyiapkan fasilitas yang memadai. (3) pimpinan fakultas perlu menjalankan peran sebagai motivator yang memberikan motivasi kepada karyawan serta memberikan reward maupun penghargaan kepada karyawan agar dalam menjalankan tugas-tugasnya selalu bersemangat dan berinisiatif.

\section{DAFTAR PUSTAKA}

Anggraeni, N. 2011. Pengaruh Kemampuan Dan Motivasi Terhadap Kinerja Pegawai Pada Sekolah Tinggi Seni Indonesia (STSI) Bandung, 12 (2:, 17.

Kantor Lembaga Penjaminan Mutu Pendidikan Provinsi Sulawesi Selatan. Jurnal Office, 2 (2): 149-154.

Keban, Yeremias T. 2000. Enam dimensi strategi administrasi Publik, Konsep Teori dan Isu. Yogjakarta: Gava Media

Mangkunegara, Prabu Anwar. 2005. Evaluasi Kinerja Sumber Daya Manusia. Bandung: Refika Aditama

Mangkunegara, Prabu Anwar. 2007. Manajemen Sumber Daya Manusia Perusahaan. Bandung: Remaja Rosdakarya

Maddy, Khairul. 2009. Hakikat dan Pengertian Pelayanan Prima. Jakarta: Chama Digit

Nasaruddin \& Muslimin. 2018. Pelaksanaan Manajemen Berbasis Sekolah (MBS) Pada SD Inpres Bira 1 Kota Makassar. JIKAP PGSD: Jurnal Ilmiah Ilmu Kependidikan, 2 (2): 95-103

Rizky, Ahmad S. 2001. Manajemen Pengganjian Karyawan Perusahaan .Jakarta: Gramedia Media Utama

Rustiani, A., Junaid, J., \& Farzan, A. 2017. Gambaran Kinerja Pegawai Puskesmas Wangi-wangi Kabupaten Wakatobi Tahun 2016. Jurnal Ilmiah Mahasiswa Kesehatan Masyarakat, 2(5).

Sedarmayanti. 2007. Manajemen Sumber daya manusia. Bandung: PT Refika Aditama

Sriwidodo, U., \& Haryanto, A. B. 2010. Pengaruh kompetensi, motivasi, komunikasi dan kesejahteraan Terhadap kinerja pegawai dinas pendidikan. Jurnal Manajemen Sumber Daya Manusia, 4 (1): 47-57.

UU5-2014AparaturSipilNegara.pdf.(t.t.). Diambil dari http://luk.staff.ugm.ac.id/ atur/UU5-2014AparaturSipilNegara.pdf

Wirawan. 2009. Evaluasi Kinerja Sumber Daya Manusia: Teori, Aplikasi, dan Penelitian. Jakarta: Salemba Empat. 